in the institute were improved when the Survey moved to a building in Østervoldgade 10. It has nevertheless been necessary to redistribute the efforts of the Survey by reducing field activity so that smaller expeditions will be sent to Greenland in the coming years. This reduction will benefit the home-based activities in Copenhagen, where greater efforts will be made to publish results and accelerate publication procedure, as the quick, efficient release of information is regarded as of great importance.

New fields of scientific investigation, where the Survey has not previously been active, were discussed in 1969. There is a growing interest in the bedrock geology under the Inland Ice as well as the off-shore areas along the coasts. The significance of new geochemical techniques for future work has also been taken into account in planning.

Finally it should be mentioned that practical arrangements to meet the rapid increase in the pressure of work which already has been felt, and can be expected to continue, as a result of the passing of the act on mineral resources, have been under consideration.

K. Ellitsgaard-Rasmussen Director

\title{
GEOLOGICAL INVESTIGATIONS IN NORTHERN PEARY LAND
}

\author{
Peter R. Dawes and N. J. Soper
}

\section{Introduction}

The authors were in North Greenland from the end of April to the beginning of September as members of the British Joint Services Expedition led by Major J. D. C. Peacock R. E. M. E. During this time reconnaissance investigations were carried out in northern Peary Land in an area about $8500 \mathrm{~km}^{2}$. Travel until mid-June was by sledge on the sea-ice, thereafter by ski and on foot in the Roosevelt Fjelde. Resupply was by parachute drops made by an RAF C-130 Hercules aircraft.

The work carried out was within the folded zone of the North Greenland Fold Belt. An attempt was made to collect enough data in the area north of Frederick E. Hyde Fjord and west to Lockwood $\varnothing$ for a geological map on the scale 1:250 000 to supplement the limited information that is available from the folded rocks of Peary Land (Koch, 1920, 1923a, 1923b, 1925; Ellitsgaard-Rasmussen, 1955; Fränkl, 1955). 
Stratigraphical rock types

Argillaceous and arenaceous rocks make up much of the folded zone but calcareous units occur in places. This is in contrast to the foreland which is mainly composed of calcareous rocks. In the north-west an area of volcanic rocks exists (see fig. 2).

In the region of Frederick E. Hyde Fjord, in Nordpasset, and in O. B. Beggild Fjord, the rock succession is composed of brown to buff weathering sandstones, often calcareous, with siltstone and shale units. The sandstones frequently display graded bedding, ripple drift bedding and bottom structures. Intercalated in the succession are conspicuous units of yellow weathering limestone breccias and conglomerates and units of dark grey to black cherts. Thin white to cream quartzite layers also exist in the successsion but in the east, south of Hundeskrænten, quartzite makes up a large area in which some conglomerate layers exist.

North of Frederick E. Hyde Fjord a mixed but dominantly argillaceous succession occurs and green, purple, buff, grey and black shales are prominent, together with some sandstones, cherts and dark limestones. These outcrop around Frigg Fjord and along the north coast of Frederick E. Hyde Fjord to the east and also in the west on Moa $\varnothing$.

The central part of the area is composed of a thick arenaceous succession (the Polkorridoren Series of Fränkl, 1955) which can be traced from the west across the Roosevelt Fjelde towards the H. H. Benedict Bjerge in the east. This is a rather monotonous brown to buff weathering, well-bedded psammitic succession. Graded units, tens of metres in thickness, are characteristic, each unit being composed of smaller graded units composed of coarse quartz-rich grit or conglomerate, micaceous feldspathic sandstone, and a subsidiary ripple-drift bedded siltstone at the top. Some parts of the group are conspicuously rich in iron pyrites, the largest cube noted being $4 \mathrm{~cm}$ in size.

North of this arenaceous succession the rocks are conspicuously metamorphic and in the inner part and south of Sands Fjord, and in the area to the east and west, a complexly folded succession of marbles, calcareous slates and phyllites, chloritic psammites, graphitic slates and rusty weathering quartz-chlorite phyllites is present. The Ulvebakkerne Marbles and the Sands Fjord Quartzphyllites of Fränkl (1955) are represented in this succession. North of this a mixed quartzite - phyllite - black schist unit occurs. In the extreme north, outcropping at the mouth of Sands Fjord and in the region of Kap Morris Jesup, is a succession of psammitic and semipelitic schists and phyllites containing chlorite, quartz, garnet and muscovite, with subsidiary pelitic garnet-chlorite-biotite schists and calcareous bands. These rocks correspond to the Kap Morris Jesup Quartzphyllites of Fränkl (1955).

Some of the rock units proposed by Fränkl (1955) are retained by the present authors, for example the Kap Morris Jesup Quartzphyllites, the Sands Fjord Quartzphyllites, the Ulvebakkerne Marbles as well as the name Polkorridoren for the central arenaceous unit. The recognition of other units in the northern part of the area is discontinued, for example the Sortevæg Marbles and Phyllites, the Nordgletscher 


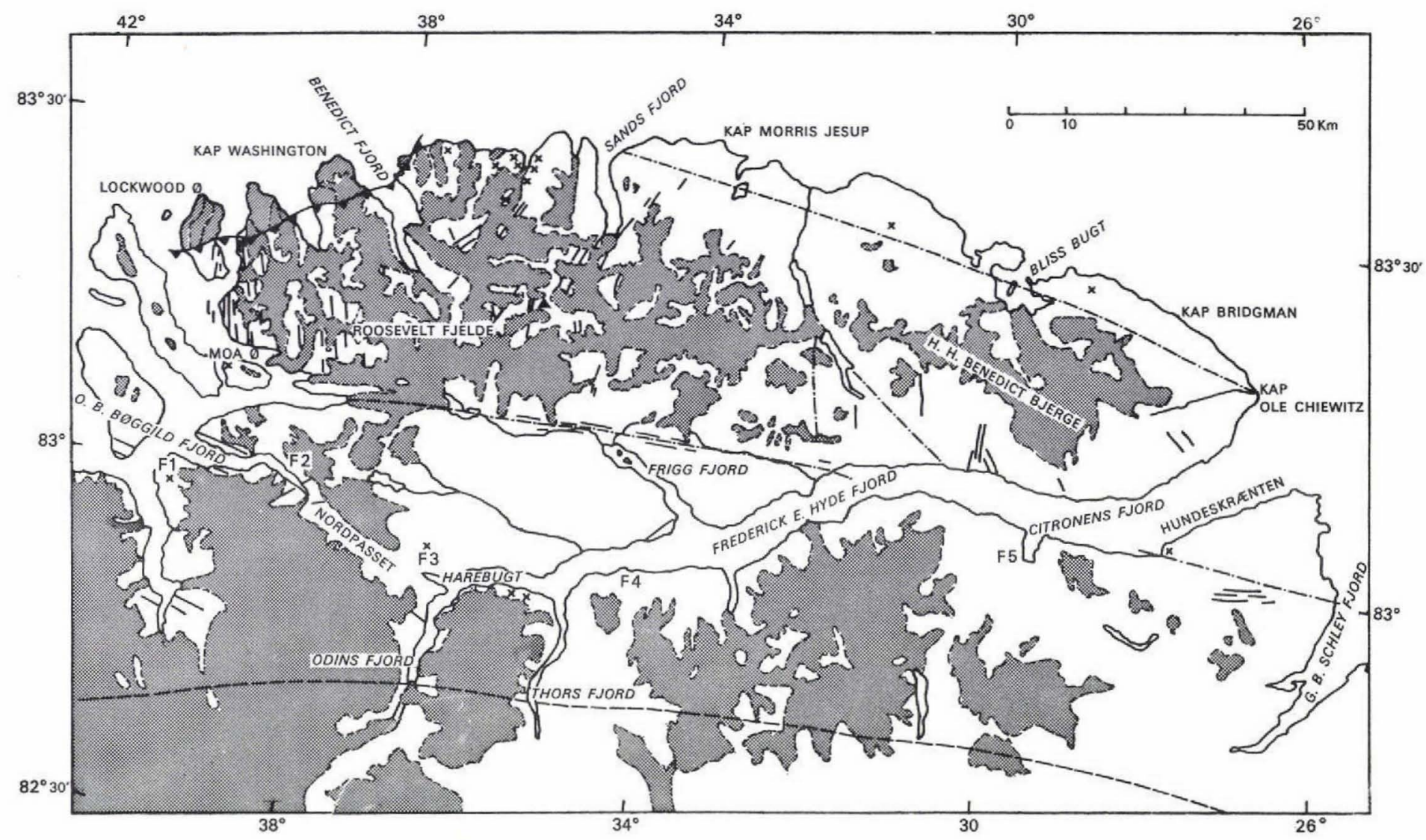

Fig. 2. Sketch map of northern Peary Land showing the localities mentioned in the text, ice-covered areas (stippled). outcrop of volcanic rocks (diagonal lines), fossil localities (F1-F5), and dykes (crosses ndicate the presence of many dykes). 
Marbles, the Paradisfjeld Marbles and Phyllites, and the Malcantone Gletscher Marbles and Slates. In this case Fränkl's four units can be shown to be a single mappable unit which has been intensely folded, rather than units separated by thrusts. In the south, north of Frigg Fjord, Fränkl's stratigraphical units have been modified, for example the Brown Series, Sydgletcher sandstones, and the Upper and Lower Nysne Gletscher graphitic slates can be placed together as the Sydgletscher Group.

A succession of volcanic rocks at least $1500 \mathrm{~m}$ thick exists on the north coast to the west of Sands Fjord. Rock types include red and black basalt and andesite, with porphyritic varieties and some breccias, rhyolites which can be homogeneous and flinty or banded and in places vesicular, zeolite-bearing lava and tuffaceous rocks, some of which resemble ignimbrites. The rocks are bounded to the south by a lowlying thrust plane along which low-grade psammitic rocks have been thrust from the south over the volcanics.

Basic intrusions

Main areas in which basic intrusions occur are shown on fig. 2. Three main groups can be recognised:

1. Metamorphosed basic rocks which occur as discordant folded layers in the psammitic schists to the west of Sands Fjord. At one locality the intrusive rock is now a garnet amphibolite.

2. Sills and dykes which occur both in the north-western part of the area and also in the south-east, to the south of Hundeskrænten, which display variable rock character. In places the rock is an ophitic textured dolerite or gabbro; elsewhere, even within the same body, the rock type appears metamorphosed and is foliated or even schistose.

3. Straight, unmetamorphosed dykes of various directions. A main N-S swarm occurs in the west of the area, a NE swarm in the area of Sands Fjord and an E-W swarm north of Frigg Fjord. The majority of these dykes are dolerites with ophitic texture, but others, in particular those dykes around O. B. Bøggild Fjord, are lamprophyric with biotite conspicuous in hand sample.

\section{Structure}

The main trend of the rocks is E-W and only in the south-west in the region around Nordpasset do the rocks markedly change in strike; here NW and even N-S trends exist. Towards the east at the entrance of Frederick E. Hyde Fjord, WNW trends exist. This apparently simple trend pattern is the result of at least three phases of deformation which produced visible folds. As pointed out by Fränkl (1955), a main structural feature of the area north of Frederick E. Hyde Fjord, particularly evident in the northern part, is the predominance of southward dipping rocks which are the result of folds overturned towards the north. As well as such northward facing structures which can reach several kilometres in amplitude, southward facing folds of both large- and small-scale were discovered.

Over much of the area the main cleavage $\left(S_{2}\right)$ is southward dipping and is an axial 
plane surface to a set of large-scale mainly asymmetrical folds $\left(\mathrm{F}_{2}\right)$ which vary from open folds with southward dipping axial planes in the south, to folds with an inverted common limb in the central area, to isoclinal folds in the north. The cleavage associated with these folds can be seen in some places to post-date an earlier cleavage $\left(\mathrm{S}_{1}\right)$ and a coaxial set of folds $\left(\mathrm{F}_{1}\right)$. Some southward facing folds can be proved to predate $S_{2}$. The axial planes of the $F_{1}$ folds have now variable dips due to the $F_{2}$ folding, but the symmetry of the $F_{1}$ axial planes where affected by $F_{2}$ suggests that $F_{1}$ axial planes were originally steep to upright, at least in the area north of Frigg Fjord. In many places refolded structures can be seen where $F_{1}$ axial planes are folded around coaxial $F_{2}$ hinges. $S_{2}$ is in places folded to form $F_{3}$ kink bands, chevron folds and even larger structures. $F_{3}$ axial planes seem to become inclined to the south at progressively lower angles as the folds are traced to the north. However the main schistosity of the rocks outcropping along the north coast is probably an $\mathrm{S}_{2}$ surface related to the northward facing structures. Early isoclines are depicted in the schists by folded leucocratic veins.

The only major thrust located in the area is the one already mentioned separating the volcanics and the overlying low grade metamorphics. Along this thrust a mylonite zone is well developed. Localities where Fränkl (1955) has proposed major E-W trending, southward dipping thrusts were visited but such thrusts could not be confirmed. Often an area which appears disrupted and might be explained by thrusting is in fact due to the interference of the fold phases mentioned above. Hence the claim that this part of north Peary Land is characterised by large overthrusts and nappe tectonics is not supported by the present field work.

\section{Metamorphism}

As shown by Fränkl (1955), the rocks of the folded zone, north of Frederick E. Hyde Fjord, vary in metamorphic grade, the highest grade rocks occurring in the north. The sediments of the south around Frederick E. Hyde Fjord are nonmetamorphic in the sense that no metamorphic minerals are conspicuous although recrystallisation has undoubtedly occurred during the deformation (see Ellitsgaard-Rasmussen, 1955, p. 43). The psammitic rocks of the central part of the area contain in places chlorite and secondary mica while chlorite, muscovite and biotite characterise the schists in the north and in the region of Kap Morris Jesup these minerals occur together along with garnet. Calc-silicate rocks to the west of Sands Fjord contain garnet and hornblende.

However the metamorphic isogrades appear not to be simply parallel to lithostratigraphical units. Some of the dolerite and gabbro dykes and sills south of Hundeskrænten mentioned in 2) above are metamorphic and the basic rock is in places foliated or even schistose. This may indicate a local variation in the position of the regional chlorite isograd. Biotite-garnet pelitic and semipelitic rocks exist on the east coast of Benedict Fjord, some way south of lower grade chlorite schists. This apparent inversion of metamorphic isograds may be due to a greenschist dynamic metamorphism 
in connection with the thrust mentioned above separating the volcanic rocks from the metasediments.

Quartz veins and streaks in the schists and psammitic rocks formed at various times during the metamorphic history, but only at certain localities along the north coast does feldspar join quartz in the leucocratic veins.

Age of the rocks and correlation

Folded, fossiliferous Cambrian, Ordovician and Silurian rocks occur in the western part of the fold belt, west of Peary Land (Dawes, 1966), but the only Palaeozoic fossils recovered hitherto from the eastern part of the fold belt are a few olenellid trilobites from folded rocks in G. B. Schley Fjord which are of Lower Cambrian age (Troelsen, 1956). Due to this almost total lack of faunal evidence from northern Peary Land it had only been possible to assume that the folded rocks of the eastern part of the fold belt are Precambrian to Silurian in age. During the summer fossils were collected from folded rocks at five localities (see fig. 2) which prove the presence of Ordovician and Silurian rocks in the Frederick E. Hyde Fjord region. Localities are F1 : dicranograptids, tetragraptids and dendroid graptolites from dark shales; F2: monograptids, tetragraptids and didymograptids from silicified shales; F3: tetragraptids and didymograptids from calcareous shales; F4: favositid corals, crinoids, solitary corals, trilobites, gastropods and brachiopods from limestone, and F5: favositid corals, crinoids and solitary corals from limestone breccia.

The limestone breccias which are common in the succession from which the Ordovician graptolites have been collected, are strikingly similar to the Ordovician breccias reported from Nyeboe Land in the western part of the fold belt (Dawes, 1966, p. 11). It also seems that the facies boundary between carbonate and clastic rocks which can be plotted in the west within the Lower Palaeozoic rocks, also occurs in Peary Land. In this case the psammitic rocks in the central part of north Peary Land may be tentatively correlated with the clastic rocks of Hall and Nyeboe Lands and also with the similar rocks examined by Ellitsgaard-Rasmussen (1955) in northwestern Peary Land.

The age of the volcanic rocks is not yet known but from general aspect the rocks appear to be younger than the main deformation which has affected the surrounding sediments. Koch (1923a, 1923b), although he only briefly mentioned the existence of "effusives" on the north coast of Greenland, regarded the rocks as younger than the main folding. The volcanics are deformed and in places cleaved, but their metamorphic grade is low compared to the surrounding metasediments which reach biotite and garnet grade. Until now all that is known about the age of the folding in North Greenland is that it is pre-Middle Pennsylvanian and post-dates the deposition of the thick clastic succession in the western part of the fold belt, the upper part of which is most probably Upper Silurian. Accurate dating of the volcanics might help to solve the age problem of the folding and might provide a means of separating the main diastrophism from a later folding and thrusting. 


\section{References}

Dawes, P. R. 1966: Lower Palaeozoic geology of the western part of the North Greenland Fold Belt. Rapp. Gronlands geol. Unders. 11, 11-15.

Ellitsgaard-Rasmussen, K. 1955: Features of the geology of the folding range of Peary Land North Greenland. Meddr Gronland 127, 7.

Fränkl, E. 1955: Rapport über die Durchquerung von Nord Peary Land (Nordgrönland) im Sommer 1953. Meddr Gronland 103, 8.

Koch, L. 1920: Stratigraphy of Northwest Greenland. Meddr dansk geol. Foren. 5, 17, 1-78.

Koch, L. 1923a: Resultaterne af Jubilæumsekspeditionen Nord om Grønland i 1921. Naturens Verden 7 , 49-76.

Koch, L. 1923b: Preliminary report upon the geology of Peary Land, Arctic Greenland. Am. J. Sci., 5th Ser. 5, 189-199.

Koch, L. 1925: Geology of North Greenland. Am. J. Sci., 5th Ser. 9, 271-285.

Troelsen, J. C. 1956: The Cambrian of North Greenland and Ellesmere Island. 20 Congr. geol. intern. México, 1956. Symp. 3. 1. 71-90.

\section{QUATERNARY STUDIES IN NORTHERN PEARY LAND}

\section{Peter R. Dawes}

In connection with the bedrock investigations reported in the previous article, some time was spent on Quaternary studies. Pelecypods for radiocarbon dating were collected from marine clay and silt at the head of O. B. Bøggild Fjord, in Nordpasset, at the head of Frigg Fjord and in Citronens Fjord on the south coast of Frederick E. Hyde Fjord. The highest level of marine sediments, over $60 \mathrm{~m}$, was noted in Nordpasset. Driftwood from raised beaches of different heights was collected on the south side of Frederick E. Hyde Fjord for possible age dating, and the heights of marine terraces were measured by hand-level at $\mathrm{O}$. B. Bøggild Fjord, at the head of Frederick E. Hyde Fjord and at the head of Citronens Fjord.

Along the north coast between Kap Ole Chiewitz and Bliss Bugt boulders and pebbles of a variety of grey and red gneisses and granites and other crystalline rocks were collected from the ground moraine. It is generally accepted that the glacial till of northern Peary Land is formed of locally derived material while that of the southern part of Peary Land, south of an approximate E-W line $33 \mathrm{~km}$ north of Independence Fjord, contains a heterogeneous assemblage which was derived both locally and from distant areas and which contains crystalline granites and gneisses (Davies. 1961). The presence of this boundary between the two types of till, which was first plotted by Koch $(1923,1928)$ and later slightly modified by Troelsen $(1952)$, is interpreted as indicating the maximum northern limit of the Greenland ice cap.

The crystalline erratics collected on the north coast clearly have not been derived from the exposed bedrock of northern Peary Land. Koch (1923, p. 64; 1928, p. 504) 